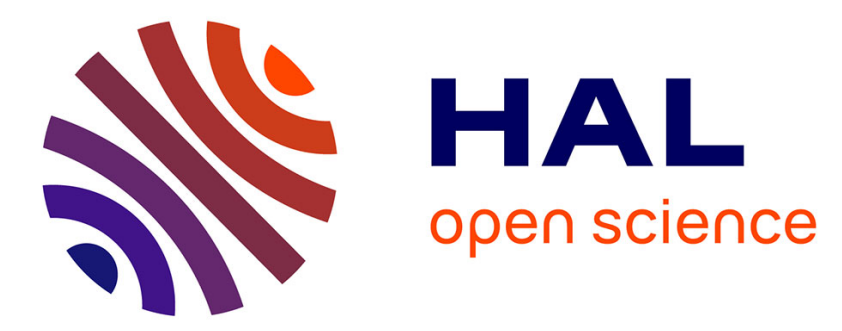

\title{
The Key Role of Production Efficiency Changes in Livestock Methane Emission Mitigation
}

Jinfeng Chang, Shushi Peng, Yi Yin, Philippe Ciais, Petr Havlik, Mario

Herrero

\section{- To cite this version:}

Jinfeng Chang, Shushi Peng, Yi Yin, Philippe Ciais, Petr Havlik, et al.. The Key Role of Production Efficiency Changes in Livestock Methane Emission Mitigation. AGU Advances, 2021, 2 (2), 10.1029/2021AV000391 . hal-03238413

\section{HAL Id: hal-03238413 \\ https://hal.science/hal-03238413}

Submitted on 27 May 2021

HAL is a multi-disciplinary open access archive for the deposit and dissemination of scientific research documents, whether they are published or not. The documents may come from teaching and research institutions in France or abroad, or from public or private research centers.
L'archive ouverte pluridisciplinaire HAL, est destinée au dépôt et à la diffusion de documents scientifiques de niveau recherche, publiés ou non, émanant des établissements d'enseignement et de recherche français ou étrangers, des laboratoires publics ou privés.

\section{(c)(1)}

Distributed under a Creative Commons Attribution| 4.0 International License 


\section{AGU Advances}

\author{
RESEARCH ARTICLE \\ 10.1029/2021AV000391 \\ Key Points: \\ - Emission intensity decreased \\ for most livestock categories \\ globally during 2000-2018, with \\ an increasing protein-production \\ efficiency \\ - The continuation of the past \\ decreases in emission intensity \\ provides a large potential to mitigate \\ livestock emissions \\ - Improving production efficiency has \\ a much greater mitigating effect than \\ demand-side efforts, and should be \\ prioritized in a few countries
}

Supporting Information:

Supporting Information may be found in the online version of this article.

Correspondence to:

J. Chang,

changjf@zju.edu.cn

Citation

Chang, J., Peng, S., Yin, Y., Ciais, P., Havlik, P., \& Herrero, M. (2021). The key role of production efficiency changes in livestock methane emission mitigation. AGU Advances, 2, e2021AV000391. https://doi. org/10.1029/2021AV000391

Received 23 JAN 2021

Accepted 2 APR 2021

Author Contributions:

Conceptualization: Philippe Ciais

Methodology: Shushi Peng

Writing - review \& editing: Shushi

Peng, Yi Yin, Philippe Ciais, Petr

Havlik, Mario Herrero
(C) 2021. The Authors.

This is an open access article under the terms of the Creative Commons Attribution License, which permits use, distribution and reproduction in any medium, provided the original work is properly cited.

\section{The Key Role of Production Efficiency Changes in Livestock Methane Emission Mitigation}

\author{
Jinfeng Chang ${ }^{1,2}$ (D), Shushi Peng ${ }^{3}$ (D), Yi Yin ${ }^{4}$ (D), Philippe Ciais ${ }^{5}$ (D), Petr Havlik ${ }^{2}$ (D), and \\ Mario Herrero ${ }^{6}$
}

${ }^{1}$ College of Environmental and Resource Sciences, Zhejiang University, Hangzhou, China, ${ }^{2}$ International Institute for Applied Systems Analysis, Laxenburg, Austria, ${ }^{3}$ Sino-French Institute for Earth System Science, College of Urban and Environmental Sciences, Peking University, Beijing, China, ${ }^{4}$ Division of Geological and Planetary Sciences, California Institute of Technology, Pasadena, CA, USA, ${ }^{5}$ Laboratoire des Sciences du Climat et de l'Environnement, LSCE/IPSL, CEA-CNRS-UVSQ, Université Paris-Saclay, Gif-sur-Yvette, France, ${ }^{6}$ Commonwealth Scientific and Industrial Research Organization, St Lucia, QLD, Australia

\begin{abstract}
The livestock sector is the largest source of anthropogenic methane emissions and is projected to increase in the future with the increased demand for livestock products. Here, we compare livestock methane emissions and emission intensities, defined by the amount of methane emitted per unit of animal proteins, estimated by different methodologies, and identify mitigation potentials in different regions of the world based on possible future projections. We show that emission intensity decreased for most livestock categories globally during 2000-2018, due to an increasing protein-production efficiency, and the IPCC Tier 2 method should be used for capturing the temporal changes in the emission intensities. We further show that efforts on the demand-side to promote balanced, healthy, and environmentally sustainable diets in most countries will not be sufficient to mitigate livestock methane emissions without parallel efforts to improve production efficiency. The latter efforts have much greater mitigating effects than demand-side efforts, and hence should be prioritized in a few developing countries that contribute most of the mitigation potential.
\end{abstract}

Plain Language Summary Livestock production represents a third of the global anthropogenic methane emissions nowadays, and the emissions are expected to keep increasing in the future. Using three sets of methodologies and emission factors from two versions of the IPCC guidelines (the 2006 and the 2019 refinement), we re-assess global livestock methane emissions over the past two decades and project the emissions till 2050. We find a decreasing trend of methane emission intensity per kg of protein produced during the past two decades. We show that promoting balanced, healthy, and environmentally sustainable diets in most countries can mitigate future livestock methane emissions, but a larger mitigation potential is projected if the past trend in decreasing emission intensity (i.e., increasing production efficiency) can be continued. We further identify major countries that have the largest mitigation potential through increasing production efficiency.

\section{Introduction}

Methane is the second-largest anthropogenic driver of current global radiative forcing after $\mathrm{CO}_{2}(\mathrm{Myhre}$ et al., 2013), and all representative concentration pathways (RCPs; Collins et al., 2013) show it maintaining this ranking in the future, thus becoming of critical importance in mitigation strategies for attaining low-warming targets. The largest anthropogenic methane source is livestock production, with the main components being the enteric fermentation of ruminants and manure management. Currently, livestock production represents a third of the global anthropogenic methane emissions, comparable to the magnitude of fossil fuels' methane emissions (Saunois et al., 2020).

Livestock emissions reported by countries to the UNFCCC are based on common methodologies provided by the IPCC Guidelines (IPCC, 1997, 2000, 2003, 2006, 2019). These guidelines give the possibility to make inventories with various levels of detail, depending on a country's capability, from the simplest Tier 1 to the most detailed Tier 3, and are periodically updated to reflect the latest expert knowledge on methodologies and emission factors. In parallel, global inventories have been developed to quantify livestock methane 
emissions for the past few decades (Chang et al., 2019; Crippa et al., 2020; Dangal et al., 2017; EPA, 2012; FAOSTAT, 2020; Janssens-Maenhout et al., 2019; Wolf et al., 2017) or for some specific years (Gerber, Steinfeld, et al., 2013; Herrero et al., 2013). These data sets cover either all livestock types (Crippa et al., 2020; EPA, 2012; FAOSTAT, 2020; Janssens-Maenhout et al., 2019; Wolf et al., 2017) or major categories (Chang et al., 2019; Dangal et al., 2017; Gerber, Steinfeld, et al., 2013; Herrero et al., 2013). Livestock methane emission estimates from inventories differ substantially depending on the choice of the methodological tier, emission factors, and livestock activity data (e.g., from globally available FAOSTAT statistics or from national/regional information). For example, estimates of emissions from enteric fermentation of ruminants in 2000, obtained from different inventories (Chang et al., 2019), range from 60.9 to $86.3 \mathrm{Tg} \mathrm{CH}_{4} \mathrm{yr}^{-1}$.

The spread between inventory estimates of livestock emissions arises from uncertainties in the intensity of emission per head of livestock, or per unit of production, such as per amount of protein. The IPCC Guidelines (2019 IPCC Refinement [IPCC, 2019]) recently updated their Tier 1 methodology for manure management emissions and revised many emission factors for livestock emissions. This major revision impacts global estimated emissions and their intensities. To our knowledge, no study has compared emission intensities derived from different methods at the global scale, although Gerber, Steinfeld, et al. (2013) produced an assessment of these quantities for a single year (2005) using the Global Livestock Environmental Accounting model (GLEAM).

According to FAOSTAT (2020), livestock methane emissions increased by 51.4\% between 1961 and 2018, following the increase in ruminant numbers and manure excretion from various livestock categories. This increasing trend will probably continue in the future, given the projected rising demand for livestock products (FAO, 2018). In developing countries, in particular, large increases in livestock production are projected, driven by the increase in per capita income and/or population. The uncertainty in emission intensities induced by the choice of method affects the future projections of livestock methane emissions, and thus climate projections.

In this study, we constructed two new estimates of global livestock methane emissions at a spatial resolution of 5 arc-min for the period 2000-2018, using both a combined Tier 1 and Tier 2 method (hereafter, 2019 Mixed Tiers, MT method) and a Tier 1 method (hereafter, 2019 T1 method) based on the latest IPCC Guidelines (IPCC, 2019) Vol. 4, Chapter 10 (Table S1). Further, we derived new estimates of emission intensities, expressed as emissions per $\mathrm{kg}$ of protein in products including milk and meat from cattle, buffaloes, goats, and sheep, meat from swine, and meat and eggs from poultry, by combining our emission estimates with the FAOSTAT production statistics (FAOSTAT, 2020). Finally, we investigated how our update to emission calculations using the latest IPCC Guidelines affects future projections from this sector by the year 2050 for three global socio-economic scenarios (FAO, 2018), and contrasted pathways of livestock production efficiency changes. To facilitate the usage of these new methods for assessing livestock methane emissions, we have provided a full package of the R code on Zenodo for producing these two new estimates and associated projections.

\section{Materials and Methods}

\subsection{Estimating Livestock $\mathrm{CH}_{4}$ Emissions Using the Mixed IPCC Tier 1 and Tier 2 Methods From the 2019 Refinement (the 2019 MT Method)}

The first set of livestock $\mathrm{CH}_{4}$ emissions was estimated using a mixture of the IPCC Tier 1 and Tier 2 methods from the the 2019 Refinement to the 2006 IPCC Guidelines for National Greenhouse Gas Inventories (IPCC, 2019) Vol. 4, Chapter 10. Enteric fermentation $\mathrm{CH}_{4}$ emissions from dairy cows, meat and other nondairy cattle, buffaloes, sheep, and goats were estimated using the IPCC Tier 2 method ([IPCC, 2019] Vol. 4, Chapter 10, Equation 10.21) based on the gross energy intake of livestock (GE) and a conversion factor, $Y_{m}$ calculated from the regional digestibility of feed (DE). For enteric fermentation emissions of other livestock, an adjusted IPCC Tier 1 method ([IPCC, 2019] Vol. 4, Chapter 10, Equation 10.19), accounting for changes in liveweight was used to estimate $\mathrm{CH}_{4}$ emissions from enteric fermentation. Text $\mathrm{S} 1$ presents a detailed description of the methods used for estimating enteric fermentation emissions.

Livestock $\mathrm{CH}_{4}$ emissions from manure management, for all livestock categories, were estimated using an updated IPCC Tier 2 method ([IPCC, 2019] Vol. 4, Chapter 10, Equation 10.23), which is based on the 
volatile solids excreted by livestock (VS), maximum methane production capacity for manure produced by livestock $\left(B_{0}\right)$, methane conversion factors $(\mathrm{MCF})$ for each manure management system and each climate region, and the fraction of livestock manure handled using each animal waste management system (AWMS) in each region. The estimation was made at the grid cell level with the following parameters: (a) distributing country level VS into grid cells following the livestock distributions in the GLW3 data set (see Section 2.4) and (b) using MCF depending on manure management system and the IPCC climate zones. Text S2 presents a detailed description of the methods used for estimating manure management emissions.

\subsection{Estimating Livestock $\mathrm{CH}_{4}$ Emissions Using IPCC Tier 1 Methods From the 2019 Refinement (the 2019 T1 Method)}

Another set of livestock $\mathrm{CH}_{4}$ emissions was estimated using the IPCC Tier 1 method updated by the 2019 Refinement to the 2006 IPCC Guidelines for National Greenhouse Gas Inventories (IPCC, 2019) Vol. 4, Chapter 10. For emissions from enteric fermentation, we used the IPCC Tier 1 method ([IPCC, 2019] Vol. 4, Chapter 10, Equation 10.19) with the total number of livestock population associated with specific $\mathrm{CH}_{4}$ emission factors for each category of livestock. The total number of livestock population was derived from the statistics of stock and producing animals (dairy cows) from the FAOSTAT (FAOSTAT, 2020) ("Live Animals" and "Livestock Primary" domains). For dairy cows, meat, and other non-dairy cattle and buffaloes, regional $\mathrm{CH}_{4}$ Tier 1 emission factors from Table 10.11 of the IPCC (2019), Vol. 4, Chapter 10 were used. For other livestock categories, emission factors from Table 10.10 of the IPCC (2019), Vol. 4, Chapter 10 were used, and factors for high and low productivity systems were applied for developed and developing countries, respectively.

For emissions from manure management, we used methane emission factors per unit of volatile solid (VS) excreted by livestock category, multiplied by the corresponding VS excretions. VS excretion for each livestock category and productivity system were calculated following Equation 10.22A of the IPCC (2019), Vol. 4 , Chapter 10. The regional VS excretion rate for each productivity system was obtained from Table 10.13A of the IPCC (2019), Vol. 4, Chapter 10, and the typical animal mass for each region and productivity system was obtained from Table 10A.5 of the IPCC (2019), Vol. 4, Chapter 10. We assumed North America, Europe, and Oceania to have only high productivity systems, while the regional shares between high $\left(S_{\text {high, } r}\right)$ and low productivity systems $\left(S_{\text {low }, r}\right)$ for Latin America, Africa, the Middle East, Asia, and India sub-continents were derived according to the regional mean live weights (Weight ${ }_{\text {mean }, r}$ ), and live weights for high (Weight high, $r_{\text {) }}$ and low productivity systems $\left(\right.$ Weight $_{\text {low }, r}$ ) as given below:

$$
S_{\text {high }, r}=\frac{\text { Weight }_{\text {mean }, r}-\text { Weight }_{\text {low }, r}}{\text { Weight }_{\text {high }, r}-\text { Weight }_{\text {low }, r}}
$$

where Weight $_{\text {mean }, r}$, Weight high, $r$, and Weight ${ }_{\text {low }, r}$ were derived from Table 10A.5 of the IPCC (2019), Vol. 4, Chapter 10. The regional shares between high $\left(S_{\text {high }, r}\right)$ and low productivity systems $\left(S_{\text {low }, r}\right)$ could only be derived for cattle, buffalo, swine, and poultry, given the data availability in Table 10A.5 of the IPCC (2019), Vol. 4, Chapter 10. For other livestock categories, values representative of high and low productivity systems were applied for developed and developing countries, respectively. The methane emission factors per unit of VS by livestock category were derived from Table 10.14 of the IPCC (2019), Vol. 4, Chapter 10, depending on the climate zone, manure management system, and production system. Therefore, we first distributed country-level VS into grid cells following the livestock distributions in the GLW3 data set (see Methods Section 2.4), then applied the fraction of livestock manure handled using each AWMS in each region, and calculated the $\mathrm{CH}_{4}$ emissions using the methane emission factors. The procedure is similar to the IPCC Tier 2 method described above but with the following additional parameters: (a) Tier 1 based VS calculation, and (b) default Tier 1 emission factors instead of $B_{0}$ and MCF.

The 2019 IPCC Refinement (IPCC, 2019) also introduced new Tier 1a emission factors for enteric fermentation to account for increases in production levels by livestock raised in countries that apply a Tier 1 methodology for estimating enteric $\mathrm{CH}_{4}$ emissions. For comparison, we additionally estimated another set of $\mathrm{CH}_{4}$ emissions from enteric fermentation using the Tier 1a method (the 2019 T1a method). For dairy cows, meat and other non-dairy cattle, and swine in Latin America, Africa, the Middle East, Asia, and India sub-continents, regional $\mathrm{CH}_{4}$ Tier 1a emission factors from Table 10.10 and Table 10.11 of the IPCC (2019), 
Vol. 4, Chapter 10 and the regional shares between high $\left(S_{\text {high, } r}\right)$ and low productivity systems, with $\left(S_{\text {low }, r}\right)$ calculated by Equation 1 given above were used. Due to the limited regional information on the production systems and on their time variation from the IPCC guideline, emissions from other livestock categories are the same as those of the $2019 \mathrm{~T} 1$ method, and the shares between high and low productivity systems are time-invariant in our estimate.

\subsection{Uncertainty Estimates}

For estimates of enteric fermentation $\mathrm{CH}_{4}$ emission from dairy cows, meat and other non-dairy cattle, buffaloes, sheep, and goats using the 2019 MT method, we assessed uncertainties due to the conversion factor $Y_{m}$. Following Tables 10.12 and 10.13 of the IPCC (2019), Vol. 4, Chapter 10, a standard deviation of $20 \%$ was applied for dairy cows, meat and other non-dairy cattle, and buffaloes, while a standard deviation of $13.4 \%$ for sheep and $18.2 \%$ for goats were applied. Table 10.10 of the IPCC (2019), Vol. 4, Chapter 10 gives an uncertainty of $\pm 30 \%-50 \%$ for the Tier 1 emission factors (validated also by the IPCC, 2019, Vol. 4, Chapter 10), which is defined as 1.96 times of the standard deviation of the mean. For uncertainty estimates of enteric fermentation $\mathrm{CH}_{4}$ emission from other livestock using the 2019 MT method, and from all livestock using the $2019 \mathrm{~T} 1$ method, we applied a median standard deviation of $40 \% / 1.96=20.4 \%$ (using $40 \%$ as a median of $\pm 30 \%-50 \%$ ). For all uncertainty estimates of manure management $\mathrm{CH}_{4}$ emission using the $2019 \mathrm{MT}$ and 2019 T1 methods, we applied a standard deviation of $30 \% / 1.96=15.3 \%$, as an uncertainty of $\pm 30 \%$ was given for the MCF used in the 2019 MT method (Table 10.17 of the IPCC, 2019, Vol. 4, Chapter 10), and also for emission factor used in the $2019 \mathrm{~T} 1$ method (Tables 10.14 and 10.15 of the IPCC, 2019, Vol. 4, Chapter 10). Uncertainties were derived from Monte Carlo ensembles $(n=1,000)$ from the range of uncertainties reported for the above parameters and/or emission factors used in the calculations. In the Monte Carlo ensembles, we assumed independent uncertainties for each livestock category, methane emissions from enteric fermentation, and manure management.

\subsection{Estimating Gridded Livestock $\mathrm{CH}_{4}$ Emissions}

The Gridded Livestock of the World v3.0 data set (hereafter referred to as the GLW3; Gilbert et al., 2018) provides global spatial distribution data for cattle, buffaloes, horses, sheep, goats, swine, chickens, and ducks in the year 2010 at a spatial resolution of 5 arc min. We estimated the gridded enteric fermentation emissions by distributing country emissions into grid cells following the GLW3 livestock distribution data (data produced from dasymetic [DA] model in Gilbert et al., 2018 were used; Table S2). We assumed no changes in the distribution of livestock during the period 2000-2018 in the gridded products, as time-variable livestock distribution data, to our knowledge, is not available at the global scale. Gridded enteric fermentation emission in grid cell $i$ of country $j$ for livestock category $k$ at year $m\left(F_{\mathrm{CH} 4-\text { Enteric }, i, j, k, m}\right)$ was calculated as follows:

$$
F_{\mathrm{CH} 4 \text {-Enteric }, i, j, k, m}=F_{\mathrm{CH} 4-\text { Enteric }, j, k, m} \times \frac{D_{\mathrm{GLW} 3, i, j, k} \times A_{i}}{\sum_{i \in j} D_{\mathrm{GLW} 3, i, j, k} \times A_{i}}
$$

where $F_{\mathrm{CH} 4-\text { Enteric }, j, k, m}$ is the total enteric fermentation emission of country $j$ for livestock category $k$ in year $m$ as calculated above, $D_{\mathrm{GLW} 3, i, j, k}$ is livestock density for category $k$ in grid cell $i$ of country $j$ from the GLW3 (unit: head $\mathrm{km}^{-2}$ ), and $A_{i}$ is the land area of grid cell $i$. For livestock categories that were not represented in the GLW3 (i.e., asses, camels, mules, and llamas), the spatial distribution of cattle was used.

The same method was used to distribute country-level VS (for both the Tier 1 and Tier 2 methods), which then were used to estimate livestock $\mathrm{CH}_{4}$ emissions from manure management at the grid cell level.

\subsection{Revisiting Emission Intensities for Livestock Production and Individual Livestock}

For economic output, we derived the methane emission intensities (including enteric fermentation and manure management emissions) per $\mathrm{kg}$ of protein produced for category $k$ in country $j$ and year $m\left(\mathrm{EF}_{\text {protein, } j, k, m}\right.$; unit: $\mathrm{kg} \mathrm{CH} 4$ per $\mathrm{kg}$ protein) as follows: 


$$
\mathrm{EF}_{\text {protein }, j, k, m}=\frac{F_{\mathrm{CH} 4-\text { Enteric }, j, k, m}+F_{\mathrm{CH} 4-\text { Manure }, j, k, m}}{P_{\text {protein }, j, k, m}}
$$

where $P_{\text {protein, } j, k, m}$ is the protein produced by livestock category $k$ in country $j$ and year $m$, and is calculated as follows:

$$
P_{\text {protein }, j, k, m}=P_{\text {meat } / \text { milk }, j, k, m} \times c_{\text {meat } / \text { milk }, k}
$$

where $P_{\text {meat/milk, }, k, m}$ is the meat and/or milk production (unit: $\mathrm{kg}$ ) by livestock category $k$ in country $j$ and

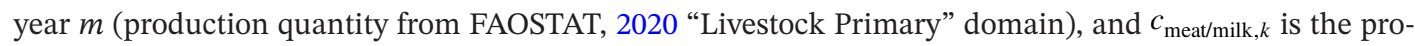
tein content of the meat or milk of livestock category $k$ (unit: $\mathrm{kg}$ protein per $\mathrm{kg}$ meat/milk). Here, we used a protein content of $0.158 \mathrm{~kg}$ protein per $\mathrm{kg}$ bovine carcass weight (cattle and buffaloes), $0.141 \mathrm{~kg}$ protein per kg sheep carcass weight, $0.134 \mathrm{~kg}$ protein per $\mathrm{kg}$ goat carcass weight, $0.131 \mathrm{~kg}$ protein per $\mathrm{kg}$ pig carcass weight, $0.143 \mathrm{~kg}$ protein per kg poultry carcass weight, $0.124 \mathrm{~kg}$ protein per kg eggs, and $0.033 \mathrm{~kg}$ protein per $\mathrm{kg}$ milk. The protein content of meat and carcass weights were derived from Table 9.1 of the GLEAM v2.0 Documentation (FAO, 2017), and the protein content of milk was calculated as $1.9+0.4 * \%$ Fat (Milk PR\% in the IPCC, 2019, Vol. 4, Chapter 10, Equation 10.33) with a typical \%Fat of 3.5\% (see IPCC, 2019, Vol. 4, Chapter 10, Table 10A.1-10A.3). It is acknowledged that meat and other non-dairy cattle and buffaloes are used as draft animals in many developing regions, especially in Asia. Hence, for developing countries, we also calculated the methane emission intensities per $\mathrm{kg}$ of protein excluding emissions from draft animals. Emissions from draft animals $\left(F_{\mathrm{CH}_{4}-\mathrm{draf} t, j, k, m}\right)$ were calculated with the IPCC Tier 2 method ([IPCC, 2019] Vol. 4, Chapter 10, Equation 10.21) using the GE of draft animals (see Text S3 for the calculation of GE).

The enteric fermentation emission intensities of country $j$ for livestock category $k$ (here, cattle, sheep, goats, and buffaloes) in year $m$ ( $\mathrm{EF}_{\text {head-Enteric, }, j, m}$; unit: $\mathrm{kg} \mathrm{CH}_{4}$ per head) are calculated as follows:

$$
\mathrm{EF}_{\text {head }, j, k, m}=\frac{F_{\mathrm{CH}_{4}-\text { Enteric }, j, k, m}+F_{\mathrm{CH}_{4}-\text { Manure }, j, k, m}}{N_{\text {head }, j, k, m}}
$$

where $N_{\text {head }, j, k, m}$ is the number of livestock (unit: head) for category $k$ in country $j$ and year $m$. For dairy cows, $N_{\text {head, } j, \text { cows }, m}$ is the number of producing animals obtained from the FAOSTAT (2020) "Livestock Primary" domain; for meat and other non-dairy cattle, $N_{\text {head, } j \text {,other cattle, } m}$ is the total stock (the FAOSTAT, 2020 "Live Animals" domain) minus the number of dairy cows; for sheep, goats, and buffaloes, $N_{\text {head, } j, k, m}$ is the total stock from the FAOSTAT (2020) "Live Animals" domain; for swine, $N_{\text {head, } j, \text { swine, } m}$ is the slaughtered number from the FAOSTAT (2020) "Livestock Primary" domain, given that their life span is usually shorter than 1 year.

\subsection{Projecting Livestock Methane Emissions}

Future livestock methane emissions depend on changes in livestock production (usually expressed in $\mathrm{kg}$ of protein) and emission intensities per livestock production (i.e., $\mathrm{kg} \mathrm{CH}_{4}$ per $\mathrm{kg}$ protein produced). Here, we projected livestock methane emissions forward until 2050, using the projected relative changes in protein production from major livestock categories under different socio-economic scenarios, and assuming different pathways of emission intensity changes. The following three socio-economic scenarios: Business As Usual (BAU), Stratified Societies (SS), and Toward Sustainability (TS), and the following two pathways where we made contrasted assumptions about production efficiency changes: constant emission intensity and improving efficiency (i.e., decreasing emission intensity) were used. Future livestock $\mathrm{CH}_{4}$ emissions for product $p$ (milk or meat) of livestock category $k$ in country $j$ and year $m$ under socio-economic scenario $s$ and emission intensity change pathway $w$ during the period 2012-2050 were calculated as follows:

$$
F_{\mathrm{CH}_{4}, j, k, m, s, w}=F_{\mathrm{CH}_{4} \text {-prod }, j, k, 2012} \times P_{\text {rel }, j, k, m, s} \times \mathrm{EF}_{\text {rel-protein }, j, k, m, w}+F_{\mathrm{CH}_{4} \text {-draft }, j, k, 2012} \times I_{\text {rel-draft }, j, k, m, w}
$$

where $F_{\mathrm{CH}_{4} \text {-prod,j,k,2012 }}$ and $F_{\mathrm{CH}_{4} \text {-draft, } j, k, 2012}$ are the methane emissions from livestock category $k$ in country $j$ and year 2012 used for production and for draft power, respectively (draft animals are meat and other 
non-dairy cattle and buffaloes used as draft power in developing countries only; see Section 2.5 for details of the emissions of draft animals); $P_{\text {rel }, j, k, m, s}$ is the change in protein production for livestock category $k$ in country $j$ and year $m$ relative to 2012 under socio-economic scenario $s ; \mathrm{EF}_{\text {rel-protein }, j, k, m, w}$ is the change in production efficiency (emission intensity per livestock production; $\mathrm{EF}_{\text {protein }, j, k, m}$ ) for livestock category $k$ in country $j$ and year $m$ relative to the 2012 value under emission intensity change pathway $w ; I_{\text {rel-draft }, j, k, m, w}$ is the change in the number of draft animals for livestock category $k$ in country $j$ and year $m$ relative to the 2012 value under production efficiency change pathway $w$. We used the year 2012 as the start of the projection since the FAO projections for livestock production started in 2012 (FAO, 2018). For livestock other than cattle, buffaloes, sheep, goats, pigs, and poultry, we assumed dynamic emissions to have their historical values during 2012-2018 and constant emissions, considering their values in 2018 for the period of 2019-2050.

The FAO (FAO, 2018) provides country level changes in productivity (raw milk and meat) and herd size for cattle, buffaloes, sheep, goats, pigs, and poultry under the following three socio-economic scenarios: BAU, SS, and TS. Data were provided for the year 2012, 2030, 2035, 2040, and 2050, and linear changes of both productivity (raw milk and meat) and herd size were assumed in this study. Given the fact that herd sizes for dairy cows and meat and other non-dairy cattle were not provided separately by the FAO, we assumed that the relative changes in herd sizes for dairy cows and meat and other non-dairy cattle are the same as the changes in cattle. Changes in protein production for livestock category $k$ in country $j$ and year $m$ relative to 2012 under socio-economic scenario $s\left(P_{\text {rel }, j, k, m, s}\right)$ were then calculated as follows:

$$
P_{\mathrm{rel}, j, k, m, s}=\frac{\sum_{p} Y_{p, j, k, m, s} \times H_{j, k, m, s} \times C_{\text {protein }, p, j}}{\sum_{p} Y_{p, j, k, 2012, s} \times H_{p, j, k, 2012, s} \times C_{\text {protein }, p, j}}
$$

where $Y_{p, j, k, m, s}$ is the productivity (unit: $\mathrm{kg}_{\text {animal }}{ }^{-1} \mathrm{yr}^{-1}$ ) for product $p$ (milk or meat) of livestock category $k$ in country $j$ and year $m$ under socio-economic scenario $s ; H_{j, k, m, s}$ is the herd size (unit: head) for livestock category $k$ in country $j$ and year $m$ under socio-economic scenario $s$; and $C_{\text {protein }, p, j}$ is the protein content (unit: $\mathrm{kg}$ protein (kg milk/meat ${ }^{-1}$ ) of product $p$ (milk or meat) of livestock category $k$ (see Section 2.5 ). For buffaloes, sheep, and goats, protein from milk and meat were summed to obtain the total protein production changes.

As outlined above, the following two variant pathways of production efficiency changes (i.e., methane emission intensity changes per kg protein produced) were assumed: "constant intensity" and "improving efficiency."

Under the "constant intensity" pathway, both $\mathrm{EF}_{\text {rel-protein, } j, k, m, w}$ and $I_{\text {rel-draft }, j, k, m, w}$ were assumed to be 1 , which means no changes in methane emission intensities per livestock production $\left(\mathrm{EF}_{\text {protein, }, k, m}\right)$ and no reduction in the numbers and methane emissions of draft animals in developing countries.

We found decreasing trends in emission intensity for major livestock categories during the past two decades due to increasing production efficiency. Based on this finding, we constructed our "improving efficiency" pathway, assuming a continuing decrease of emission intensity. Under this pathway, the future will see (a) a continuation of the country-specific historical trends of the development of gross domestic product (GDP) per capita for countries showing decreasing emission intensity during the past two decades; and (b) constant emission intensities for countries that experienced no change or an increasing emission intensity in the past two decades. For each country, a regression between the emission intensity per kg of protein over four periods (2000-2004, 2005-2009, 2010-2014, 2014-2017) and the corresponding GDP per capita was calculated to derive the country-specific trends of emission intensities from the projections of GDP per capita. Note that the last period only contains four years because the GDP per capita from the FAOSTAT (2020) is only available until 2017. We calculated the regression for these periods, rather than on an anual basis, to avoid the impact of potentially strong inter-annual variation of the emission intensities due to temporary effects such as livestock epidemics or economic shocks. We calculated the emission intensity per kg protein production for livestock category $k$ in country $j$ and year $m$ relative to $2012 \mathrm{EF}_{\text {rel-protein }, j, k, m, s}$ as follows:

$$
\mathrm{EF}_{\text {rel-protein }, j, k, m, s}=\frac{\mathrm{EF}_{\text {protein }, j, k, m, s}}{\mathrm{EF}_{\text {protein }, j, k, 2012}}
$$


where $\mathrm{EF}_{\text {protein, } j, k, 2012}$ is the emission intensity per $\mathrm{kg}$ of protein production for livestock category $k$ in country $j$ in 2012; and $\mathrm{EF}_{\text {protein }, j, k, m, s}$ is the future emission intensity per kg of protein for livestock category $k$ in country $j$ in year $m$ under socio-economic scenario $s$, which is calculated as follows:

$$
\mathrm{EF}_{\text {protein }, j, k, m, s}=a_{j, k} \times \text { GDPperCapita }_{j, s}+b_{j, k}, \text { when } a_{j, k}<0
$$

where GDPperCapita $_{j, s}$ is the GDP per capita in country $j$ in year $m$ under socio-economic scenario $s$ given by the FAO (2018); $a_{j, k}$ and $b_{j, k}$ are the regression coefficients representing the trend and intercept, respectively, from the regression between the emission intensity per $\mathrm{kg}$ of protein over four periods (2000-2004, 2005-2009, 2010-2014, 2014-2017) and the corresponding GDP per capita during the historical period. Equation 9 only applies to countries showing decreasing emission intensities during the past two decades (i.e., $a_{j, k}<0$ ). For countries with no change or increasing emission intensities in the past two decades (i.e., $a_{j, k} \geq 0$ ), a constant emission intensity is applied. Furthermore, to avoid unrealistically low emission intensities in the future, we set a minimum emission intensity per $\mathrm{kg}$ of protein for each livestock category $k$ $\left(\mathrm{EF}_{\text {protein }, k, \mathrm{~min}}\right)$ as a threshold. This is derived as the 0.05 -quantile of the emission intensities per kg of protein from all countries with more than 100 tonnes of protein production per year for that livestock category during the most recent 5-year period (2014-2018). The thresholds varied with the different methods used (the 2019 MT, the 2019 T1, or the 2006 T1 method) and are listed in Table S3. Figure S17 provides the number of countries that reach the minimum emission intensity per kg of protein for each livestock category by 2050 , and the protein production of these countries under the "improving efficiency" pathway.

The following additional sensitivity pathway of production efficiency changes (i.e., methane emission intensity changes per kg protein produced) was considered: (a) a continuation of the country-specific trend of the development of the GDP per capita for countries showing decreasing emission intensity during the past two decades; and (b) a continuation of the country-specific trend of the development of GDP per capita for countries showing increasing emission intensity during the past two decades. For countries showing decreasing emission intensities, same as the "improving efficiency" pathway, we set a minimum emission intensity per $\mathrm{kg}$ of protein for each livestock category $k\left(\mathrm{EF}_{\text {protein, } k \text {,min }}\right)$ as a threshold to avoid unrealistically low emission intensities. Similarly, to avoid unrealistically low emission intensities for countries showing increasing emission intensities, we set a maximum emission intensity per $\mathrm{kg}$ of protein for each livestock category $k\left(\mathrm{EF}_{\text {protein }, k, \max }\right)$ as a threshold. This is derived as the 0.95 -quantile of the emission intensities per $\mathrm{kg}$ of protein from all countries with more than 100 tonnes of protein production per year for that livestock category during the most recent 5-year period (2014-2018). The thresholds varied with the different methods used (the 2019 MT, the 2019 T1, or the 2006 T1 method) and are listed in Table S4.

\section{Estimated Livestock Methane Emissions and Recent Changes}

The magnitude of global livestock methane emissions estimated for 2010 using our 2019 MT method (122 $\pm 13 \mathrm{Tg} \mathrm{CH}_{4} \mathrm{yr}^{-1}$; Figure 1a) is consistent with that estimated by EDGAR v4.3.2 (Janssens-Maenhout et al., 2019) (115 $\mathrm{Tg} \mathrm{CH}_{4} \mathrm{yr}^{-1}$ ), EDGAR v5.0 (Crippa et al., 2020) (113 $\mathrm{Tg} \mathrm{CH}_{4} \mathrm{yr}^{-1}$ ), and (Wolf et al., 2017) $\left(118 \pm 18 \mathrm{Tg} \mathrm{CH}_{4} \mathrm{yr}^{-1}\right)$. All these data sets consider trends in liveweight and/or productivity of livestock (Table S1). They are all higher than those of the most recent FAOSTAT (FAOSTAT, 2020) data (104 $\mathrm{Tg} \mathrm{CH}_{4}$ $\mathrm{yr}^{-1}$ ) and the US EPA data set (EPA, 2012) (103 $\left.\mathrm{Tg} \mathrm{CH}_{4} \mathrm{yr}^{-1}\right)$. The FAOSTAT used the default $2006 \mathrm{~T} 1$ emission factors, while the US EPA data set (EPA, 2012) used the $2006 \mathrm{~T} 1$ supplemented by country-reported inventory data. We found a higher estimate using the new $2019 \mathrm{~T} 1$ method $\left(130 \pm 14 \mathrm{Tg} \mathrm{CH}_{4} \mathrm{yr}^{-1}\right)$, which is explained by higher emission factors (Table S4) for both enteric fermentation and manure management, and changes in the method used for estimating manure management to reflect the latest livestock characteristics. Global estimates using the 2019 T1a method (see Section 2.2) are nearly the same as those using the 2019 T1 method ( $<0.2 \%$ differences; Table S2) with differences ranging from $0.01 \%$ to $3.4 \%$ in regional estimates, thus, we do not discuss the emissions using the 2019 T1a method hereafter. It should be kept in mind that it is a purely academic exercise to show the effect of the different Tiers on total livestock methane emissions. As emphasized in the 2019 IPCC Refinement (IPCC, 2019) Vol. 4, Chapter 10, Section 10.3.1, "the Tier 2 method should be used if enteric fermentation is a key source category for the animal category that represents a large portion of the country's total emissions," and "the Tier 1 method is likely to be suitable 

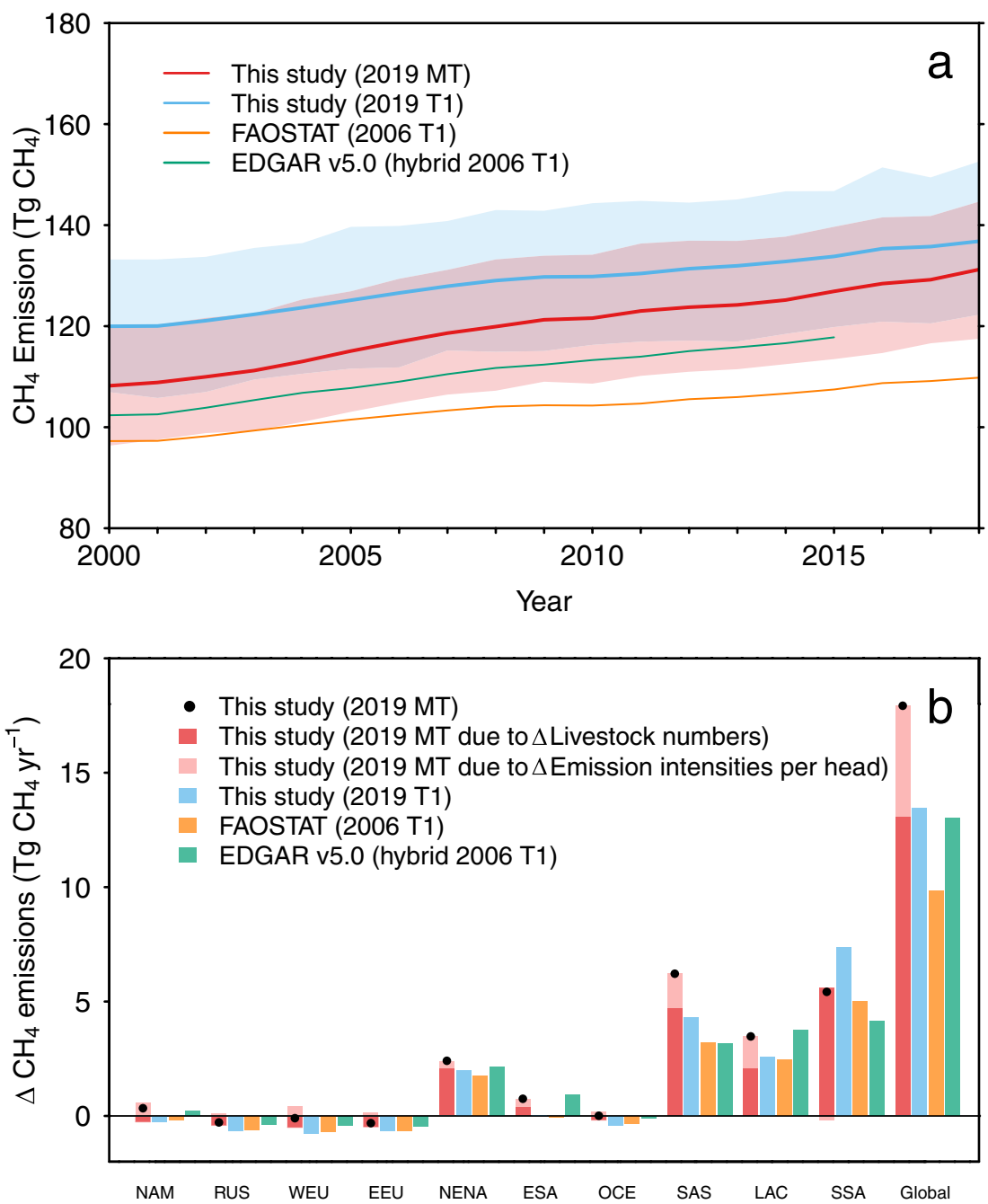

Figure 1. Global livestock methane emission changes from 2000 to 2018 (a), and global and regional changes in livestock methane emissions between the periods 2000-2004 and 2014-2018 (b). The shaded area indicates the 1-sigma standard deviation of the estimates using the 2019 MT and the 2019 T1 methods in this study. Uncertainties were derived from Monte Carlo ensembles $(n=1,000)$ from the range of uncertainties reported for various parameters and/ or emission factors used in the calculations (see Methods). In the Monte Carlo ensembles, we assume independent uncertainties for each livestock category, and for methane emissions from enteric fermentation and manure management. Contributions due to the changes in livestock numbers and to the changes in emission intensities per head are shown separately in (b). For EDGAR v5.0, the changes in (b) are between the periods 2000-2004 and 2014-2015. Regions are classified following the definition of the FAO Global Livestock Environmental Assessment Model (GLEAM): NAM, North America; RUS, Russia; WEU, western Europe; EEU, eastern Europe, NENA, Near East and North Africa; EAS, eastern Asia; OCE, Oceania; SAS, south Asia; LAC, Latin America and Caribbean; SSA, SubSaharan Africa.

for most animal species in countries where enteric fermentation is not a key source category, or where enhanced characterization data are not available.”

Globally, we found that $88 \%-91 \%$ of the livestock methane emissions come from enteric fermentation (Table S2), and are dominated by cattle, sheep, goats, and buffaloes. The share of the total emissions attributed to different livestock categories varies between regions, while the pattern is similar between our two estimates and the FAOSTAT (2020) (Figure S1). There are significant regional differences in livestock methane emissions between the four data sets (Figure S2), mainly due to the revised Tier 1 enteric fermentation emission factors used in the 2019 Guidelines and the Tier 2 method (the 2019 MT in Figure S2). We also established gridded livestock methane emission fields by downscaling our national totals (Figure S3), which 
can provide valuable high-resolution prior information for atmospheric inverse studies. These emission maps show higher livestock methane emission intensity per area of land, compared to EDGAR v5.0 (Crippa et al., 2020), in the Sahel countries, Eastern Africa, South Asia, Eastern China, and Northeast Australia, but lower values in Europe and Latin America (Figures S4a and S4c).

Temporal changes of livestock methane emissions in the last two decades or so (2000-2018) were quantified as the difference between the values in 2000-2004 and those in 2014-2018. We found that global emissions increased by +10 to $+18 \mathrm{Tg} \mathrm{CH}_{4} \mathrm{yr}^{-1}$ between these two periods (Figure 1b), the largest increase being found with our 2019 MT method and the lowest with the FAOSTAT. The 2019 MT method accounts for changes in productivity through varying liveweight and production (see Methods), and thus allows attribution of the increase to changes in livestock numbers versus emission intensities per head. We estimated that $73 \%$ of the increase in global emissions between the two periods is explained by increasing livestock numbers, the remaining $27 \%$ due to increasing emission intensities per head in most regions (i.e., larger mean body size and higher meat and milk production per head).

Regional analysis gives, however, a more nuanced picture of the role of these two drivers (Figure 1b; Figure S5). The most noticeable increases in emissions between the two periods were found in South Asia $(+3$ to $+6 \mathrm{Tg} \mathrm{CH}_{4} \mathrm{yr}^{-1}$ ) and Sub-Saharan Africa (+4 to $+7 \mathrm{Tg} \mathrm{CH}_{4} \mathrm{yr}^{-1}$; see also Figure S6). For the $2019 \mathrm{MT}$ emission estimates, $24 \%$ of the increase in South Asia during the period 2000-2018 can be attributed to changes in emission factors per head, while the entire increase in emissions in Sub-Saharan Africa is explained by rising livestock numbers. Moderate increases were found in Latin America, Near East and North Africa, and East and Southeast Asia. On the other hand, estimated emissions decreased in the developed regions between the two periods when using the Tier 1 methods, while estimates using the 2019 MT method showed slightly increased emissions in North America, and almost constant emissions in other developed regions as increasing yield and liveweight were accounted for.

Dairy cows (+2 to $\left.+6 \mathrm{Tg} \mathrm{CH}_{4} \mathrm{yr}^{-1}\right)$ and meat and other non-dairy cattle $\left(+2\right.$ to $\left.+4 \mathrm{Tg} \mathrm{CH}_{4} \mathrm{yr}^{-1}\right)$ in developing countries are the major contributors to the increase of livestock methane emissions during 2000-2018, followed by buffaloes in South Asia (+2 to $+3 \mathrm{Tg} \mathrm{CH}_{4} \mathrm{yr}^{-1}$; Figure S5). Sheep in Near East and North Africa, East and Southeast Asia, and Sub-Saharan Africa, goats in Sub-Saharan Africa, and swine in East and Southeast Asia also contributed significantly to the regional emission increases (Figure S5).

\section{Revised Estimates of Emission Intensities for Livestock Protein Production and the Recent Changes}

We analyzed estimates of emission intensities per $\mathrm{kg}$ of protein production for each livestock category, as derived from the following : (a) protein production figures given by livestock production commodities statistics from the FAOSTAT (2020) and their protein content obtained from the GLEAM model (FAO, 2017), and (b) emissions estimates using our new 2019 MT and 2019 T1 calculations, and the 2006 T1 method (i.e., data from the FAOSTAT, 2020).

During 2014-2018, methane emission intensity per $\mathrm{kg}$ of protein produced is the lowest for poultry meat and eggs (0.02-0.08 $\mathrm{kg} \mathrm{CH}_{4}$ per $\mathrm{kg}$ protein at global scale), followed by swine meat (0.3-0.5 $\mathrm{kg} \mathrm{CH}_{4}$ per $\mathrm{kg}$ protein), because of negligible enteric fermentation emissions from monogastric (Figure 2). Ruminant meats have the highest methane emission intensity per $\mathrm{kg}$ of protein among major livestock products. At the global scale, we estimated intensities of 3.5-4.2 $\mathrm{kg} \mathrm{CH}_{4}$ per kg protein for beef cattle, 3.8-5.5 $\mathrm{kg} \mathrm{CH}_{4}$ per $\mathrm{kg}$ protein for goats, and 4.1-5.0 $\mathrm{kg} \mathrm{CH}_{4}$ per kg protein for sheep. Higher methane emission intensities of goats and sheep meat than that of beef are mainly due to the low digestibility of feed (low-quality roughage). On the other hand, it means that goats and sheep depend less on human-edible feed and avoid foodfeed competition (Mottet et al., 2017; Van Zanten et al., 2018). Cow milk production has a global average methane emission intensity of $1.0-1.2 \mathrm{~kg} \mathrm{CH}_{4}$ per $\mathrm{kg}$ of protein, lower than meat production because of (a) the higher protein production efficiency of milk compared with meat, and (b) a more protein-rich and digestible diet given to milking cows. Buffaloes are mostly used as draft animals in Asia with only a small fraction of them being used for meat and milk production. Excluding the emissions from draft animals, the global average methane emission intensity for buffalo meat and milk, which is essentially only produced in Asia and some European countries, ranges from 2.0-3.0 $\mathrm{kg} \mathrm{CH}_{4}$ per $\mathrm{kg}$ of protein. Accounting for all the 

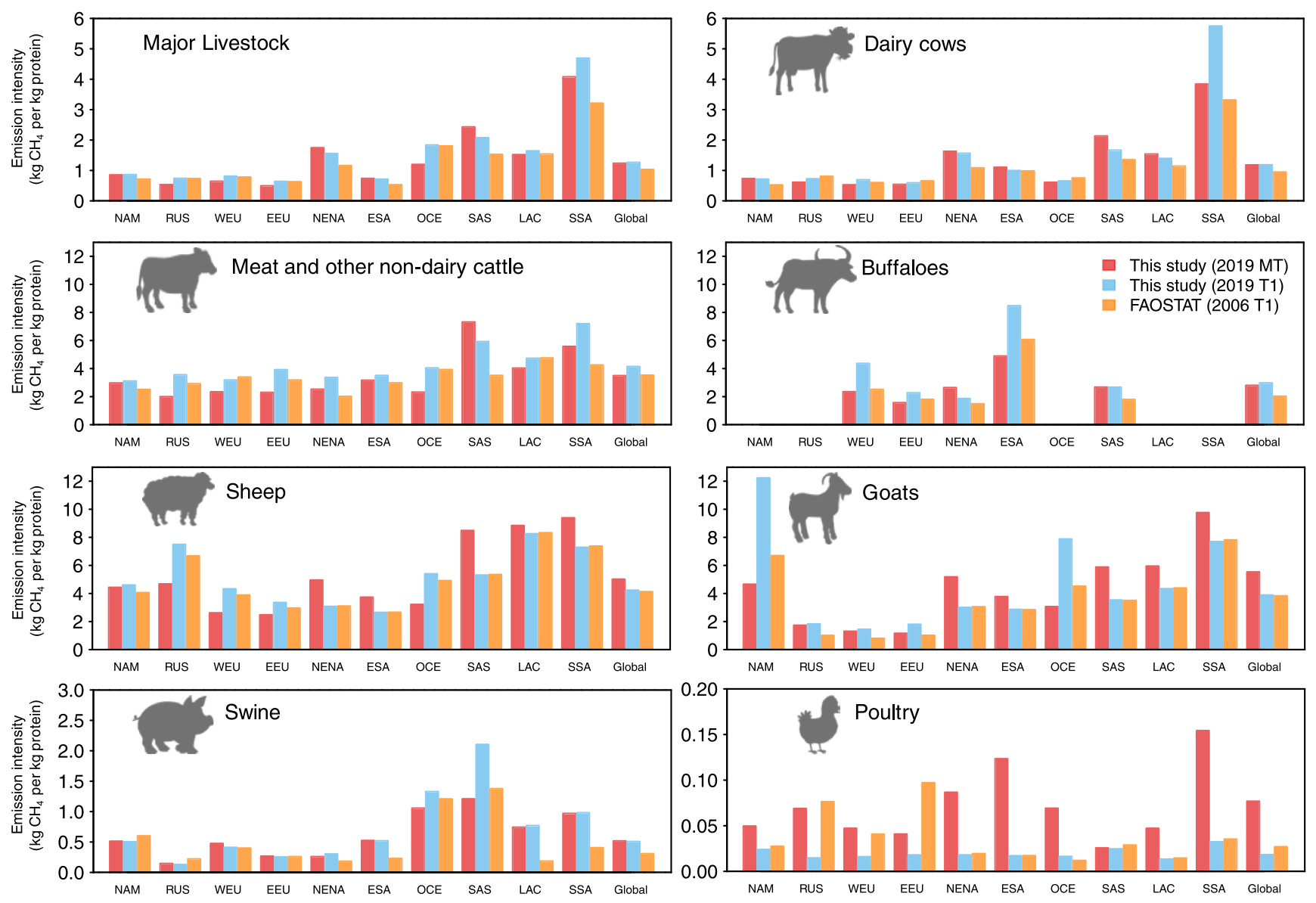

Figure 2. Livestock $\mathrm{CH}_{4}$ emission intensities (including enteric fermentation and manure management emissions) per kg of protein produced during the period 2014-2018 for major livestock categories. Emissions from draft animals were excluded from the calculation. Regions are classified following the definition of the FAO Global Livestock Environmental Assessment Model (GLEAM): NAM, North America; RUS, Russia; WEU, western Europe; EEU, eastern Europe, NENA, Near East and North Africa; EAS, eastern Asia; OCE, Oceania; SAS, south Asia; LAC, Latin America and Caribbean; SSA, Sub-Saharan Africa.

above seven major protein-producing livestock, globally the weighted average emission intensity ranges from 1.0-1.3 $\mathrm{kg} \mathrm{CH}_{4}$ per $\mathrm{kg}$ of protein (Figure 2).

For ruminant products, intensity differences between regions are mainly due to differences in productivity, themselves explained by differences in diet and/or grazing intensity, with a less nutritious/digestible diet (e.g., low protein and high fiber) and/or more extensive grazing (ruminants only) leading to higher emissions. However, for swine and poultry, it is the management of manure that dominates methane emissions, and regional differences in emission intensities depend on climate (with warmer climate enhancing emissions) and the manure management system. The choice of a method to calculate emissions, affects the global and regional emission intensity per kg of protein for each livestock product, with the strongest differences being for poultry (Figure 2). The differences in intensities between regions and between livestock categories can also have different signs across the different methods (i.e., not always higher or lower intensities from one method compared to another).

During the past two decades, the emission intensity decreased for most livestock categories at the global scale (but not in all countries), indicating an increasing protein-production efficiency (Figure 3). The emission intensity for meat and other non-dairy cattle, however, shows slight changes. Using the 2019 MT method, globally the weighted average emission intensity of the seven major protein-producing livestock categories decreased by $9 \%$ (Figure 3 ). The attribution shows that $30 \%$ of the changes are due to changes in the emission per kg of protein of different livestock categories, while $66 \%$ are due to changes in the mixture of livestock categories. The latter comes from the faster increase in protein from poultry with low emission 

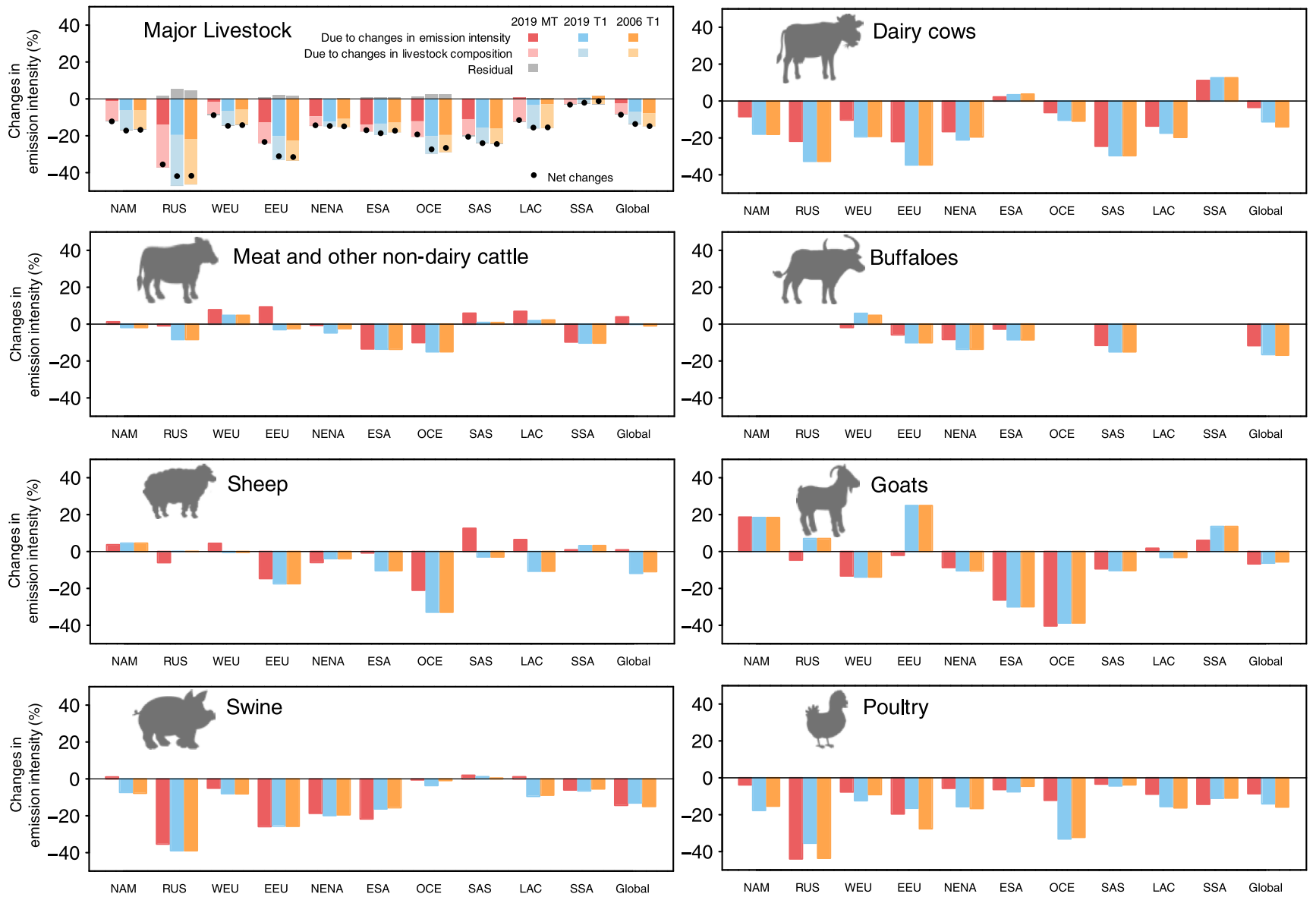

Figure 3. Relative changes in livestock $\mathrm{CH}_{4}$ emission intensities per kg of protein produced from 2000-2004 to $2014-2018$ for major livestock categories. For a livestock category, the changes between the two periods were expressed as percentage change of emission intensities during 2014-2018 compared to that during 2000-2004. For the seven major livestock categories together, the net changes in emission intensities (black points) were attributed: (1) to the changes due to the changes in emission intensity of each livestock category; (2) to the changes in the livestock composition; and (3) to the residual between the net changes and the sum of (1) and (2). Emissions from draft animals were excluded from the calculation.

intensities ( $+51 \%$ between 2000-2004 and 2014-2018) than that from ruminants with high emission intensities (+28\% between 2000-2004 and 2014-2018; Figure S7). Using the 2006 or 2019 T1 methods, however, larger decreases in the weighted average emission intensity were estimated (around 14\%), and they were mainly attributed to changes in the emission intensities per $\mathrm{kg}$ of protein of different livestock categories (53\%).

It is noteworthy that the intensity changes obtained using the 2019 MT method usually show smaller decreases, or even increases in emission intensities per protein production than the estimates using the other two methods (Figure 3). The estimates using the 2006 or $2019 \mathrm{~T} 1$ methods consider the fixed emissions per head of livestock, and underestimate the increasing trend of total emissions caused by the increasing yield and liveweight (Figure 1b). Thus, with an increasing trend of protein production per head of livestock in reality, using the 2006 or $2019 \mathrm{~T} 1$ methods partly overestimates the decreasing trend from emission intensities per protein production. Our results highlight the key role of accounting for methane emissions due to productivity and liveweight changes (as in the 2019 MT method) in capturing the temporal changes in the emission intensities per protein production.

The changes in the weighted average emission intensity vary between regions (Figure 3). The largest relative decrease was found in Russia, followed by Eastern Europe, South Asia, and Oceania. In contrast, Sub-Saharan Africa only shows a slight decrease (3\%). In North America, Western Europe, Russia, and Latin America, the decrease is mainly $(>66 \%)$ due to the changes in the mixture of livestock categories, with faster 

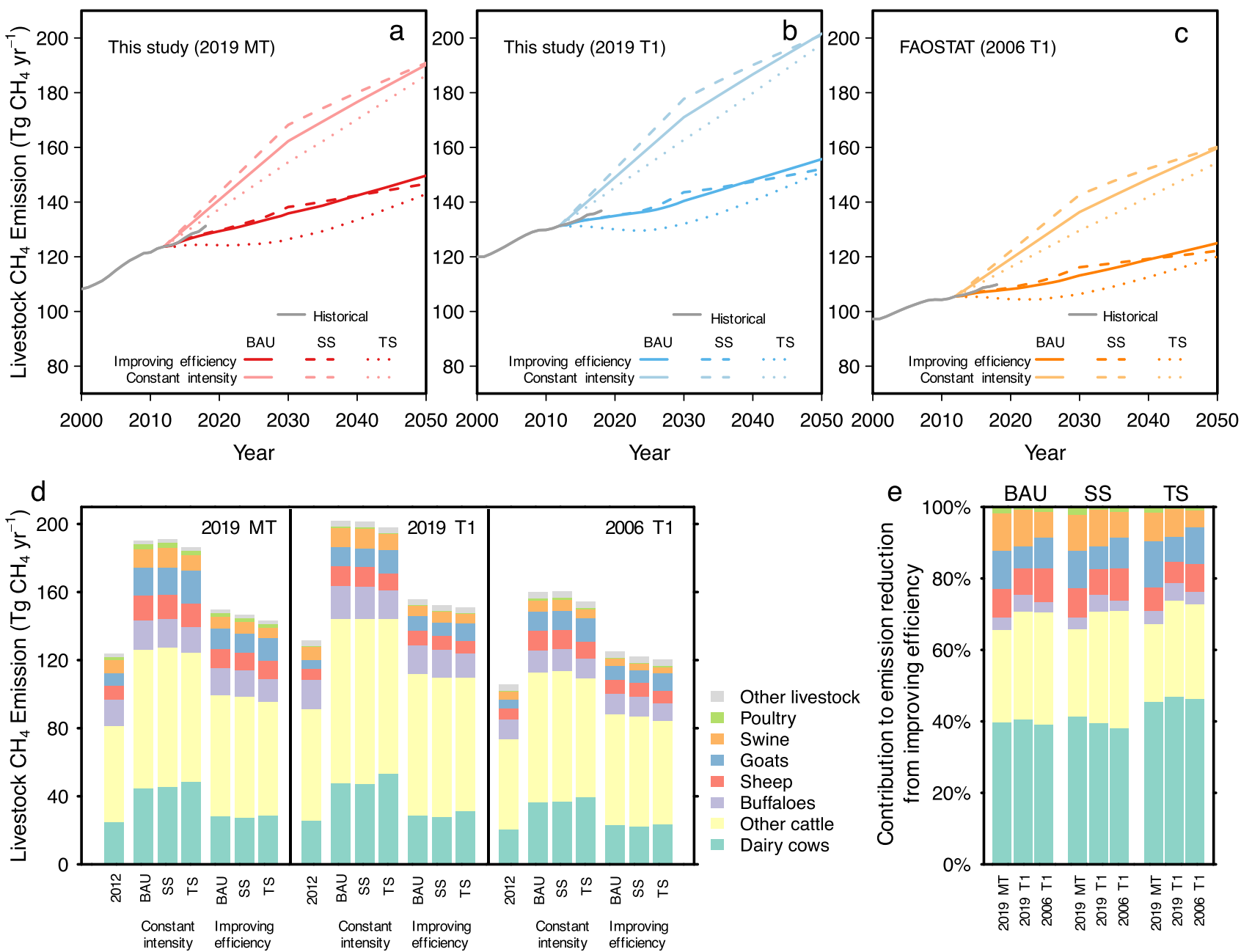

Figure 4. Projections of global livestock methane emissions under different socio-economic scenarios and emission intensity change pathways (a-c), emission contribution of each livestock category (d), and each livestock category's share of contribution to emission reduction from improving efficiency (e). Socioeconomic scenarios: Business As Usual (BAU), Stratified Societies (SS), and Toward Sustainability (TS). Emission intensity change pathways: Constant emission intensity per kg protein and improving efficiency with decreasing emission intensity per kg protein.

increases in protein from pigs and poultry with low emission intensities than in ruminants with high emission intensities. In the Near East and North Africa, Eastern and Southeast Asia, and Oceania, the decrease is mainly $(>63 \%)$ due to the changes in the emission per $\mathrm{kg}$ of protein of different livestock categories. These widespread decreases in regional emission intensities observed in the past two decades imply the potential of improving production efficiency to mitigate livestock emissions.

\section{Future Projections of Livestock Methane Emissions}

Combining the category-specific methane emission intensities per kg of protein (dairy cows, meat and other non-dairy cattle, buffaloes, sheep, goats, swine and poultry) and the FAO's projections on future livestock production (FAO, 2018), we projected future livestock methane emissions up to 2050 under different socio-economic scenarios (see Methods).

Assuming constant emission intensities, as in the period 2014-2018 (referred to as "Constant intensity" pathway), and keeping emission intensities values from the new 2019 MT method, the global livestock methane emissions were projected to increase by 51\%-54\% from 2012 to 2050 under different socio-economic scenarios (FAO, 2018) (i.e., reach 186-191 $\mathrm{Tg} \mathrm{CH}_{4} \mathrm{yr}^{-1}$ in 2050; Figure 4a). The relative increases are 
similar with the $2006 \mathrm{~T} 1$ (46\%-52\%) and $2019 \mathrm{~T} 1$ methods (51\%-53\%; Figures 4b and 4c) because of the same changes in protein production from the FAO (2018) and constant emission intensities in this projection.

For the past two decades, we have shown in the previous section that methane emission intensity per kg protein for various livestock categories in each region has been observed to decrease (Figure 3; Figure S8) following the increases in productivity. The changes in productivity could be empirically related to the development of GDP per capita. Country-specific past trends in emission intensity for major livestock categories were estimated from regressions between the emission intensity and GDP per capita (see Section 2.6, and Figure S9 as examples). In the "Improving efficiency" pathway (i.e., decreasing emission intensity per $\mathrm{kg}$ of protein), we assumed the following: (a) a continuation of the country-specific past trend with the development of GDP per capita for countries showing decreasing emission intensity during the past two decades; and (b) constant emission intensity for countries with no changes or increasing emission intensity in the past (Figure S8). We find that this reasonable scenario of "Improving efficiency" (e.g., Figure S10) can reduce future livestock emissions by a large amount compared to baselines where intensity is constant in the future (Figure 4d). Global livestock methane emissions were projected to increase by only $15 \%-21 \%$ from 2012 to 2050 using the new 2019 MT method (reach 143-150 $\mathrm{Tg} \mathrm{CH}_{4} \mathrm{yr}^{-1}$ by 2050; Figure 4a). Similar relative increases were estimated using the 2006 T1 (15\%-19\%) and 2019 T1 methods (14\%-18\%; Figures 4b and $4 \mathrm{c}$ ). Additional sensitivity projections were conducted with a continuation of the country-specific past trend with the development of GDP per capita allowing both increasing or decreasing emission intensity in the future (see Methods). Global livestock methane emissions were projected to increase from 2012 to 2050 by $34 \%-35 \%, 30 \%-33 \%$, and 31\%-33\% using the 2019 MT, the $2019 \mathrm{~T} 1$, and the $2006 \mathrm{~T} 1$ methods, respectively (Figure S11).

The higher emission intensities per kg of protein from either the 2019 MT or the 2019 T1 method, compared to the $2006 \mathrm{~T} 1$ method, led to projections of larger livestock methane emissions in the future, for a given scenario of livestock numbers and production from the FAO (2018). The projections using the new 2019 MT and 2019 T1 methods are 18\%-21\% and 24\%-28\% higher, respectively, than that given by the 2006 T1 method (Figures 4a-4c). Moving to the methodology of the 2019 IPCC Refinement(IPCC, 2019) is important, as the differences can be substantial, particularly in regions such as Sub-Saharan Africa, Near East and North Africa, and South Asia, where large positive trends on livestock production (Figure S12) and emissions (Figure S13) are projected in the future scenarios. In the SSP database (Riahi et al., 2017) (https:// tntcat.iiasa.ac.at/SspDb/), the projections for greenhouse gas emissions by Integrated Assessment Models (IAMs) were first harmonized for a base year of 2015 to the historical inventory from FAOSTAT. Our results suggest that using historical emissions from the FAOSTAT as a reference in the IAMs underestimates future emissions. The updated historical emissions by the 2019 MT and 2019 T1 methods in this study could be used as references in the IAMs. We further provided alternative pathways on emission intensity per kg of protein production based on country-specific past trend with the development of GDP per capita. They can be considered as supplementary scenarios of emission intensities for the IAMs projections.

\section{The Key Role of Production Efficiency Changes in Emission Mitigation}

While we found that the differences in the projections among different socio-economic scenarios are small (Figures 4a-4c), global livestock methane emissions under the TS scenario were projected to be lower than those under the BAU and SS scenarios. This is due to the similar global ruminant protein production (as dominant methane emitters) across the three socio-economic scenarios by 2050 (Figure S12). At the same time, the continuation of the past decreases in emission intensity provides large potential to mitigate livestock emissions (Figures 4a-4c). The estimated mitigation can be mainly contributed by the efficiency change for dairy cows (contributing $38 \%-46 \%$ of the total reduction by 2050; Figure 4e and Figure S14) followed by meat and other non-dairy cattle (contributing $22 \%-33 \%$ of the total reduction by 2050). Sheep, goats, and swine also contributed a significant share of the emission reduction, ranging between $5 \%$ and $13 \%$ of the total reduction by 2050.

Livestock productivity of milk and beef in most developed countries is already high nowadays (methane emission intensity is already low; Figure 2), and there is only little room for methane reduction through productivity increase (Figure S10). On the other hand, further productivity increase requires high shares 


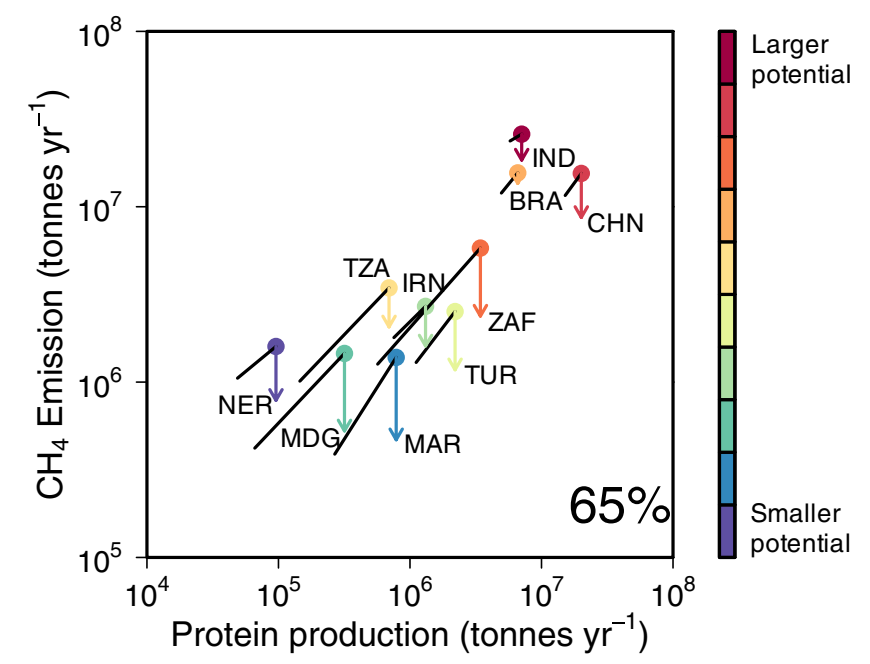

Figure 5. Projections on the increase in protein production, methane emission, and the effects of improving efficiency on reducing livestock methane emissions for all livestock under Business As Usual (BAU) scenarios, resulting from the 2019 MT method. The black lines indicate the protein production ( $x$-axis) and methane emission ( $y$-axis) from 2012 (start of black lines) to 2050 (dots). The arrows indicate the emission reduction potential by 2050 due to improving efficiency compared to the baseline where emission intensity is constant in the future. Results for the top 10 countries/areas with the largest mitigation potential for all livestock were presented, with their ISO3 country codes (http://www.fao.org/ countryprofiles/iso3list/en/) annotated near the dots or arrows. The redyellow-violet color scheme represents the mitigation potential from large to small. The number presented in percentage indicates the contribution of these 10 countries/areas in global total mitigation potential. Countries/ areas were presented as ISO3 country codes. of concentrates (i.e., potential competition with human nutrition from plant-based food [Gill et al., 2010]) and encounters potential health problems in cows (see review by Herzog et al., 2018). In addition, the intensive livestock breeding and management have resulted in fragile systems that do not adequately handle their manure, causing air and water pollution. There is a trend that some developing countries are moving from high efficiency systems toward more extensive livestock systems (such as "free range" chicken and grass-fed beef; e.g., Cheung \& McMahon, 2017). Therefore, there is a possibility that the emission intensity per $\mathrm{kg}$ of protein in those developed countries will increase, which is the opposite of our assumption of constant decreasing emission intensity.

The potential is the largest in developing countries where the current efficiency is low (i.e., emission intensity per $\mathrm{kg}$ protein is high) and a large increase in livestock production is projected. For example, in our projections under the BAU scenario, $60 \%-65 \%$ of the global reduction in livestock emissions by 2050 due to improving efficiency (compared to baselines where intensity is constant in the future) can be contributed by the top 10 countries with the largest reduction potential (Figure 5 and Figures S15-S17). Most of them are the developing countries in Asia, South America, and Africa.

The continuation of past decreases in emission intensity, especially in developing countries, can be achieved through the transition of livestock production systems from extensive rangeland systems to mixed crop-livestock systems (Frank et al., 2018; Havlík et al., 2014), and through improving livestock management within the existing systems (Thornton \& Herrero, 2010). Various factors can contribute to such a transition: for instance, better breeding, fertility and health intervention (Gill et al., 2010), better quality feed (Gill et al., 2010; Johnson \& Johnson, 1995), and optimization of grazing management (e.g., forage storage to avoid losing weight in winter [Thornton \& Herrero, 2010]). In addition, new technologies, such as feed supplements, can also reduce methane emissions from rumen (Caro et al., 2016; Gerber, Hristov, et al., 2013), while methane emissions from manure management can be mitigated through various options, such as improving housing systems, manure storage, composting, and anaerobic digestion (Gerber, Hristov, et al., 2013). However, there are adaptability issues and side-effects that must be considered when implementing these strategies. For example, breeding practices from temperate regions may not adapt well to the warm conditions in Africa. A shift in productivity might involve an increase in the consumption of grain-based feed and/or high-quality fodder in the diet, but it can also be effectively achieved through better roughage quality and better grazing management. For example, in semi-arid regions where increasing crop production for feeding livestock is impossible due to water limitations (e.g., central Asia), improving grazing management to increase productivity should be prioritized as a sustainable solution rather than moving from low to industrialized systems (i.e., landless livestock systems with livestock fed by grain-based feed and/or high-quality fodder). Improving livestock production efficiency should always be in line with the natural circumstances in the respective region. The optimal strategy should also consider other relevant sustainability goals such as biodiversity, water pollution through nutrient runoff, and potential implications for livelihoods and resilience to climate change impacts.

Our results highlight the fact that (a) efforts on the demand-side to promote balanced, healthy and environmentally sustainable diets in most counties, as assumed in the TS scenario (FAO, 2018), will not be sufficient for livestock methane emission mitigation without parallel efforts to improve production efficiency and decrease the emission intensity per unit protein produced; and (b) efforts to decrease emission intensity should be prioritized in a few developing countries with the largest mitigation potential. 


\section{Conflict of Interest}

The authors declare no conflict of interest.

\section{Data Availability Statement}

The data used in this study are available in the Supporting Information. The raw data are from the FAO: http://www.fao.org/faostat/en/\#data and http://www.fao.org/global-perspectives-studies/food-agriculture-projections-to-2050/en/. The results of this study, and the R code and the parameter files used to produce them are available at following website: https://doi.org/10.5281/zenodo.4663448.

\section{Acknowledgments}

Jinfeng Chang is supported by the Strategic Priority Research Program of the Chinese Academy of Sciences (Grant No. XDA26010303). Philippe Ciais acknowledges support from the CLAND Convergence Institute of the French National Research Agency (ANR). Mario Herrero acknowledges funding from the Bill and Melinda Gates Foundation through the MERLIN project (INV-023682).

\section{References}

Caro, D., Kebreab, E., \& Mitloehner, F. M. (2016). Mitigation of enteric methane emissions from global livestock systems through nutrition strategies. Climatic Change, 137(3), 467-480. https://doi.org/10.1007/s10584-016-1686-1

Chang, J., Peng, S., Ciais, P., Saunois, M., Dangal, S. R. S., Herrero, M., et al. (2019). Revisiting enteric methane emissions from domestic ruminants and their $\delta 13 \mathrm{CCH} 4$ source signature. Nature Communications, 10(1), 3420. https://doi.org/10.1038/s41467-019-11066-3

Cheung, R., \& McMahon, P. (2017). Back to grass: The market potential for US grassfed beef. Stone Barns Center for Food and Agriculture.

Collins, M., Knutti, R., Arblaster, J., Dufresne, J.-L., Fichefet, T., Friedlingstein, P., et al. (2013). Long-term climate change: Projections, commitments and irreversibility. In Climate change 2013-The physical science basis: Contribution of working group I to the fifth assessment report of the intergovernmental panel on climate change (pp. 1029-1136). Cambridge University Press.

Crippa, M., Solazzo, E., Huang, G., Guizzardi, D., Koffi, E., Muntean, M., et al. (2020). High resolution temporal profiles in the Emissions Database for Global Atmospheric Research. Scientific Data, 7(1), 121. https://doi.org/10.1038/s41597-020-0462-2

Dangal, S. R. S., Tian, H., Zhang, B., Pan, S., Lu, C., \& Yang, J. (2017). Methane emission from global livestock sector during 1890-2014: Magnitude, trends and spatiotemporal patterns. Global Change Biology, 23(10), 4147-4161. https://doi.org/10.1111/gcb.13709

EPA. (2012). Global anthropogenic non-CO2 greenhouse gas emissions: 1990-2030. United States Environment Protection Agency.

FAO. (2017). Global livestock environmental assessment model-Model description version 2.0 (GLEAM 2.0).

FAO. (2018). The future of food and agriculture-Alternative pathways to 2050.

FAOSTAT. (2020). Retrieved from http://www.fao.org/faostat/en/\#home

Frank, S., Beach, R., Havlík, P., Valin, H., Herrero, M., Mosnier, A., et al. (2018). Structural change as a key component for agricultural non-CO2 mitigation efforts. Nature Communications, 9(1), 1060. https://doi.org/10.1038/s41467-018-03489-1

Gerber, P. J., Hristov, A. N., Henderson, B., Makkar, H., Oh, J., Lee, C., et al. (2013). Technical options for the mitigation of direct methane and nitrous oxide emissions from livestock: A review. Animal, 7(s2), 220-234. https://doi.org/10.1017/s1751731113000876

Gerber, P. J., Steinfeld, H., Henderson, B., Mottet, A., Opio, C., Dijkman, J., et al. (2013). Tackling climate change through livestock: A global assessment of emissions and mitigation opportunities. Food and Agriculture Organization of the United Nations (FAO).

Gilbert, M., Nicolas, G., Cinardi, G., Van Boeckel, T. P., Vanwambeke, S. O., Wint, G. R. W., \& Robinson, T. P. (2018). Global distribution data for cattle, buffaloes, horses, sheep, goats, pigs, chickens and ducks in 2010. Scientific Data, 5, 180227. https://doi.org/10.1038/ sdata.2018.227

Gill, M., Smith, P., \& Wilkinson, J. M. (2010). Mitigating climate change: The role of domestic livestock. Animal, 4(3), 323-333. https://doi. org/10.1017/s1751731109004662

Havlík, P., Valin, H., Herrero, M., Obersteiner, M., Schmid, E., Rufino, M. C., et al. (2014). Climate change mitigation through livestock system transitions. Proceedings of the National Academy of Sciences of the United States of America, 111(10), 3709-3714. https://doi. org/10.1073/pnas.1308044111. Retrieved from https://www.pnas.org/content/pnas/111/10/3709.full.pdf

Herrero, M., Havlik, P., Valin, H., Notenbaert, A., Rufino, M. C., Thornton, P. K., et al. (2013). Biomass use, production, feed efficiencies, and greenhouse gas emissions from global livestock systems. Proceedings of the National Academy of Sciences of the United States of America, 110(52), 20888-20893. https://doi.org/10.1073/pnas.1308149110

Herzog, A., Winckler, C., \& Zollitsch, W. (2018). In pursuit of sustainability in dairy farming: A review of interdependent effects of animal welfare improvement and environmental impact mitigation. Agriculture, Ecosystems \& Environment, 267, 174-187. https://doi. org/10.1016/j.agee.2018.07.029. Retrieved from https:/www.sciencedirect.com/science/article/pii/S0167880918303128

IPCC. (1997). Revised 1996 IPCC guidelines for National Greenhouse Inventories.

IPCC. (2000). Good practice guidance and uncertainty management in National Greenhouse Gas Inventories.

IPCC. (2003). Good practice guidance for land use, land- use change and forestry.

IPCC. (2006). 2006 IPCC guidelines for National Greenhouse Gas Inventories (Vol. 4). Institute for Global Environmental Strategies.

IPCC. (2019). 2019 refinement to the 2006 IPCC guidelines for National Greenhouse Gas Inventories (Vol. 4). IPCC.

Janssens-Maenhout, G., Crippa, M., Guizzardi, D., Muntean, M., Schaaf, E., Dentener, F., et al. (2019). EDGAR v4.3.2 Global Atlas of the three major greenhouse gas emissions for the period 1970-2012. Earth System Science Data, 11(3), 959-1002. https://doi.org/10.5194/ essd-11-959-2019. Retrieved from https://www.earth-syst-sci-data.net/11/959/2019/

Johnson, K. A., \& Johnson, D. E. (1995). Methane emissions from cattle. Journal of Animal Science, 73(8), 2483-2492. https://doi. org/10.2527/1995.7382483x

Mottet, A., de Haan, C., Falcucci, A., Tempio, G., Opio, C., \& Gerber, P. (2017). Livestock: On our plates or eating at our table? A new analysis of the feed/food debate. Global Food Security, 14, 1-8. https://doi.org/10.1016/j.gfs.2017.01.001. Retrieved from https://www. sciencedirect.com/science/article/pii/S2211912416300013

Myhre, G., Shindell, D., Bréon, F. M., Collins, W., Fuglestvedt, J., Huang, J., et al. (2013). Anthropogenic and natural radiative forcing. In T. F. Stocker, D. Qin, G. K. Plattner, M. Tignor, S. K. Allen, J. Doschung, A. Nauels, Y. Xia, V. Bex, \& P. M. Midgley (Eds.), Climate change 2013: The physical science basis. Contribution of working group I to the fifth assessment report of the intergovernmental panel on climate change (pp. 659-740). Cambridge University Press. 
Riahi, K., van Vuuren, D. P., Kriegler, E., Edmonds, J., O’Neill, B. C., Fujimori, S., et al. (2017). The Shared Socioeconomic Pathways and their energy, land use, and greenhouse gas emissions implications: An overview. Global Environmental Change, 42, 153-168. https:// doi.org/10.1016/j.gloenvcha.2016.05.009

Saunois, M., Stavert, A. R., Poulter, B., Bousquet, P., Canadell, J. G., Jackson, R. B., et al. (2020). The global methane budget 2000-2017. Earth System Science Data, 12(3), 1561-1623. Retrieved from https://essd.copernicus.org/articles/12/1561/2020/

Thornton, P. K., \& Herrero, M. (2010). Potential for reduced methane and carbon dioxide emissions from livestock and pasture management in the tropics. Proceedings of the National Academy of Sciences of the United States of America, 107(46), 19667-19672. https://doi. org/10.1073/pnas.0912890107

Van Zanten, H. H. E., Herrero, M., Van Hal, O., Röös, E., Muller, A., Garnett, T., et al. (2018). Defining a land boundary for sustainable livestock consumption. Global Change Biology, 24(9), 4185-4194. https://doi.org/10.1111/gcb.14321

Wolf, J., Asrar, G. R., \& West, T. O. (2017). Revised methane emissions factors and spatially distributed annual carbon fluxes for global livestock. Carbon Balance and Management, 12(1), 16. https://doi.org/10.1186/s13021-017-0084-y 